九州大学学術情報リポジトリ

Kyushu University Institutional Repository

\title{
Key Factors of Solar Energy Progress in Bangladesh unt il 2017
}

\section{Marzia, Khanam}

Interdisciplinary Graduate School of Engineering Sciences, Kyushu University I International Institute for Carbon-Neutral Energy Research, Kyushu University

Hasan, Muhammad Faisal

Interdisciplinary Graduate School of Engineering Sciences, Kyushu University

Miyazaki, Takahiko

Interdisciplinary Graduate School of Engineering Sciences, Kyushu University | International Institute for Carbon-Neutral Energy Research, Kyushu University

Saha, Bidyut Baran

International Institute for Carbon-Neutral Energy Research, Kyushu University

他

https://doi.org/10.5109/1936220

出版情報 : Evergreen. 5 (2)，pp.78-85，2018-06. 九州大学グリーンアジア国際リーダー教育センター バージョン：

権利関係 : 


\title{
Key Factors of Solar Energy Progress in Bangladesh until 2017
}

\author{
Marzia Khanam ${ }^{1,2 *}$, Muhammad Faisal Hasan ${ }^{1}$, Takahiko Miyazaki ${ }^{1,2}$, Bidyut Baran \\ Saha $^{2}$, Shigeru Koyama ${ }^{1,2}$ \\ ${ }^{1}$ Interdisciplinary Graduate School of Engineering Sciences, Kyushu University, Japan \\ ${ }^{2}$ International Institute for Carbon-Neutral Energy Research, Kyushu University, Japan \\ *Author to whom correspondence should be addressed, \\ Marzia Khanam \\ E-mail: khanam_marzia@yahoo.com
}

(Received April 9, 2018; accepted June 4, 2018).

\begin{abstract}
Renewable energy (RE) is the potential solution to the current world's problems pertaining to the energy crisis and environmental concerns. Like other countries Bangladesh, which is currently starving for energy, has given more importance to RE especially solar energy to mitigate the energy-related problems. According to RE policy of Bangladesh, the targeted RE share was $5 \%$ to be achieved by 2015 (500 MW). At the beginning of 2018, the country was able to install 506 MW from RE sources (3.10\%), in which significant portion comes from solar energy. The factors that contributed mainly to achieve the target are government policies and initiatives, international influence, solar panel price reduction, private sector participation, public awareness. In this study, the influences of these factors have been discussed. Besides, the technologies implemented for the fulfillment of RE share target has been analyzed.
\end{abstract}

Keywords: Bangladesh, solar energy, progress, potential, factors.

\section{Introduction}

\subsection{General information about Bangladesh}

The People's Republic of Bangladesh is a South-Asian country which has coordinates $20^{\circ} 34^{\prime}$ 'and $26^{\circ} 38^{\prime}$ ' north latitude and $88^{\circ} 01^{\prime}$ and $92^{\circ} 41^{\prime}$ east longitude. Fig.1 shows the geographical location of Bangladesh. The total area of the country is $147,570 \mathrm{~km}^{2}$. It has eight divisions, namely Dhaka, Chittagong, Rajshahi, Barisal, Sylhet, Khulna, Mymensingh and Rangpur. The meteorological condition of the country can be divided into six distinct seasons which are summer, monsoon, autumn, late-autumn, winter, and spring. In summer, the average temperature is $27.75^{\circ} \mathrm{C}$ where the average temperature is $20^{\circ} \mathrm{C}$ in winter ${ }^{11}$.

Currently the total population of the country is almost 166 million and its position is $8^{\text {th }}$ based on the lists of the populated countries in the world ${ }^{2}$. The population density of the country is increasing in every year. There was a drastic change in population density within the year 1990 to 2018. In 1990, the population density was 816 people $/ \mathrm{km}^{2}$ which becomes 1,278 people $/ \mathrm{km}^{2}$ in 2018. However, the adult literacy rate in the country is $72.76 \%$ according to the statistics of $2016^{3)}$. Almost 65\% of the total population live in the rural areas ${ }^{5}$.

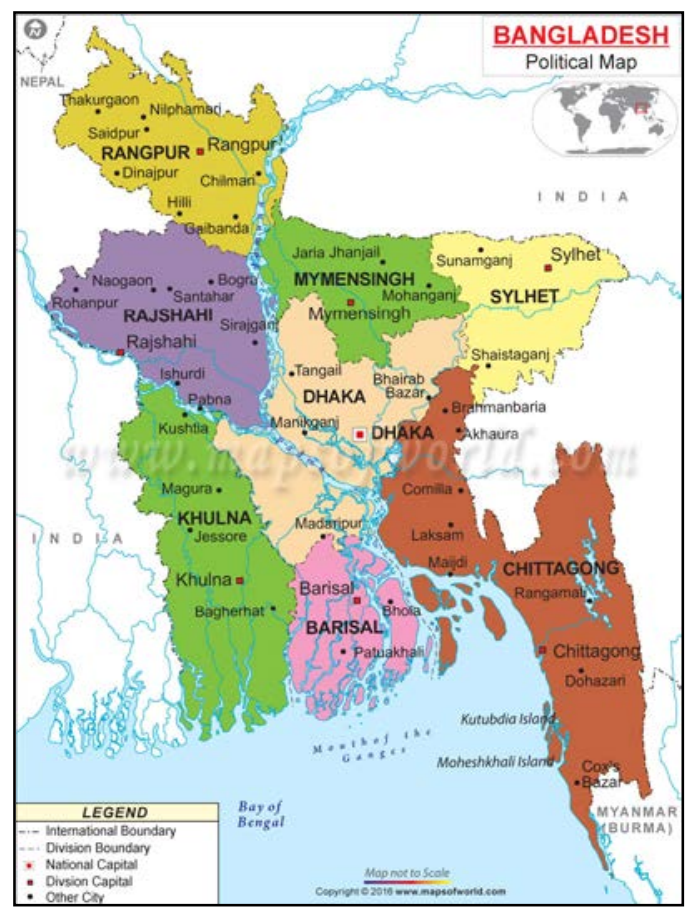

Fig. 1: Geographical map of Bangladesh ${ }^{4}$ 
Therefore, agriculture is the main profession for the people. Besides, agriculture is the leading driving force of the economy of the country. Fishing, manufacturing, power sector and retail trade are the other remarkable professions. Moreover, industrialization is an emergent sector in the country due to the low-cost labor.

\subsection{Present energy status}

Electricity is the primary impetus for urbanization, industrialization and economic growth. As in 2015, 68\% people of the total population have the electricity access in Bangladesh and per capita electricity consumption was $348 \mathrm{kWh}$, which is low assessed with other developing country ${ }^{6}$. Per capita energy consumption is an essential parameter for the development of a country and it has a reciprocal relationship with GDP growth as well, which exposed in some recent studies ${ }^{7}$.

Though net energy generation is increasing every year, however, still it is not at a satisfactory level. In 2012, it was 33,397 GWh where it became 57,276 GWh in 2017 8). More than $70 \%$ enhancement in net energy generation ensued within last six years (2012 to 2017). Current electricity generation mix by fuel type (including off-grid $\mathrm{RE}$ ) is displayed in fig. 2.

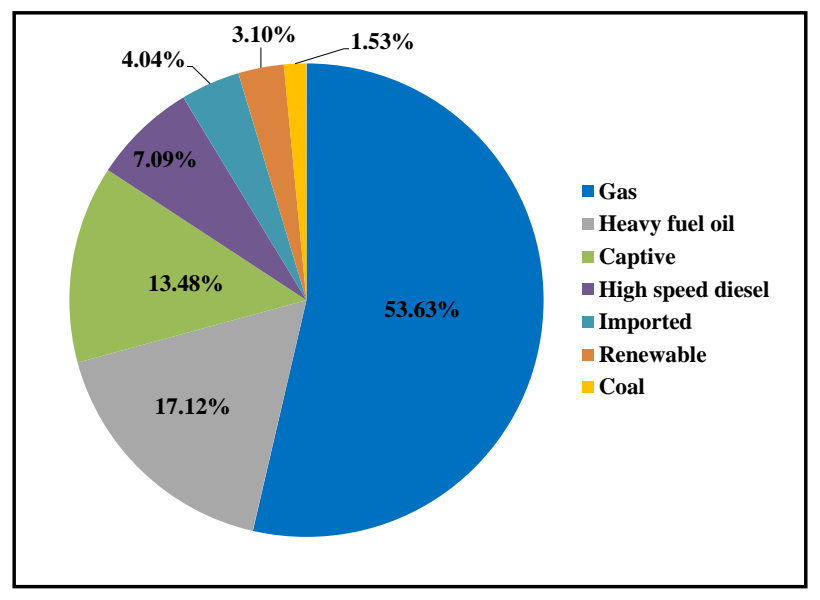

Fig. 2: Electricity generation mix ${ }^{9)}$

For electricity generation, Bangladesh mainly depends on fossil fuels where the dominating energy source is natural gas. Power plants, industry sector, fertilizer factories and transport sector are reliant on natural gas. Almost $54 \%$ of total energy consumption comes from natural gas ${ }^{8)}$. Other notable energy sources are oil, coal, and diesel.

According to current estimation, Bangladesh will face a severe energy crisis in upcoming years if the mono-fuel dependency on natural gas continues. It is expected that total power demand will rise nearly 24,000 MW ${ }^{10)}$ in 2021 where current power generation capacity is approximately 16,321 MW (including Off-Grid RE) in $2018^{9 \text { ). }}$

Therefore, it is mandatory to move towards alternative energy sources to ensure energy security in future.

\subsection{Potential renewable energy sources in Bangladesh}

Renewable energy (RE) is the energy source that is ample in nature and it is not depleted by means of continuous utilization. Besides, $\mathrm{RE}$ is environment benign and sustainable energy. Bangladesh is sanctified with plentiful RE sources like solar, biomass, wind and hydropower energy. However, within the renewables, solar, biomass and biogas are the most suitable resources considering the geographical location and socio-economic conditions of Bangladesh. As Bangladesh is a country of flat land and here water head is low, therefore, only small-scale hydropower is favorable. Inadequate information about wind energy makes the use of this to a small extent. However, still Bangladesh is not using their RE sources effectively.

At present, RE shares among the total electricity generation in Bangladesh is only $3.10 \%{ }^{9)}$ where the value in the world accounts $23.5 \%$ of total energy generation in $201{ }^{11)}$. Among the renewables, solar, wind, hydro, biomass and biogas are used in Bangladesh. The share of RE by fuel type is shown in fig. 3. For next-generation energy sufficiency and energy security, Bangladesh needs to develop more RE facility as other developed countries are doing ${ }^{12)}$. Like Hawaii, USA and Okinawa, Japan is installing more RE facilities to ensure next-generation energy mix and to reduce the cost of energy generation ${ }^{13)}$.

From fig. 3, it is seen that the maximum share of RE in Bangladesh comes from solar energy which is $53.7 \%$ of total RE ( 272MW). The usage of solar energy in this country mainly started at 2010. However, up to now, it has achieved a huge success. Fig. 4 shows the power generation from solar energy from 2010 to 2017.

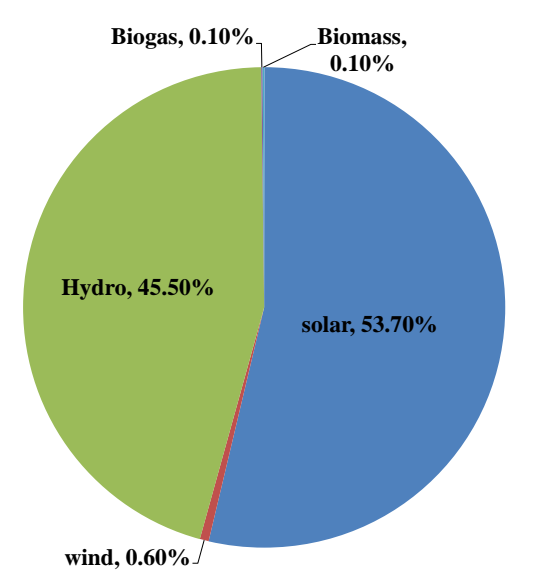

Fig. 3: Renewable energy share by fuel type ${ }^{9)}$

In this study, the progress of solar energy for the period of 2010 to 2017 has been discussed comprehensively and the influencing factors behind the flourishment of solar energy are explained. 


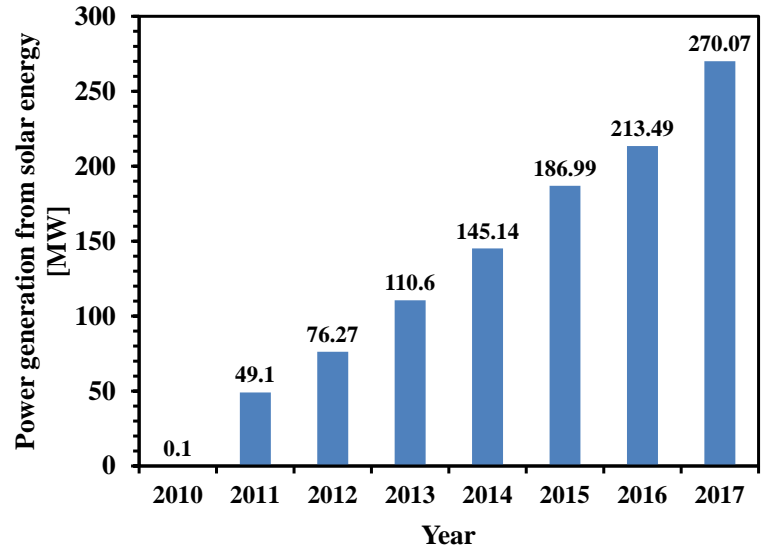

Fig. 4: power generation from solar energy (including off-grid) ${ }^{9)}$

\section{Solar energy situation in Bangladesh}

\subsection{Solar energy availability}

Solar energy is the most favorable RE source to mitigate the current energy crisis problem around the world. On the earth surface, annual solar radiation is nearly 3,400,000 exajoule (EJ). The generated electric power from the available solar insolation is $1700 \mathrm{TW}$ theoretically and the approximation is that world's current power demand could be solved by $1 \%$ of that energy ${ }^{14)}$. Geographical location of Bangladesh assists her to receive a considerable amount of solar energy throughout the year. Annual existing solar radiation is more than $1900 \mathrm{kWh} / \mathrm{m}^{2}$ whereas average daily solar radiation varies within the range of $4-6.5 \mathrm{kWh} / \mathrm{m}^{2}$. In fig. 5 , average monthly solar irradiation of six divisional districts of Bangladesh has been exhibited. From fig. 5, it is evident that Rajshahi district has the maximum solar irradiation comparing with other divisional districts. Besides, from March to May solar radiation is maximum while November to January it gets the minimum.

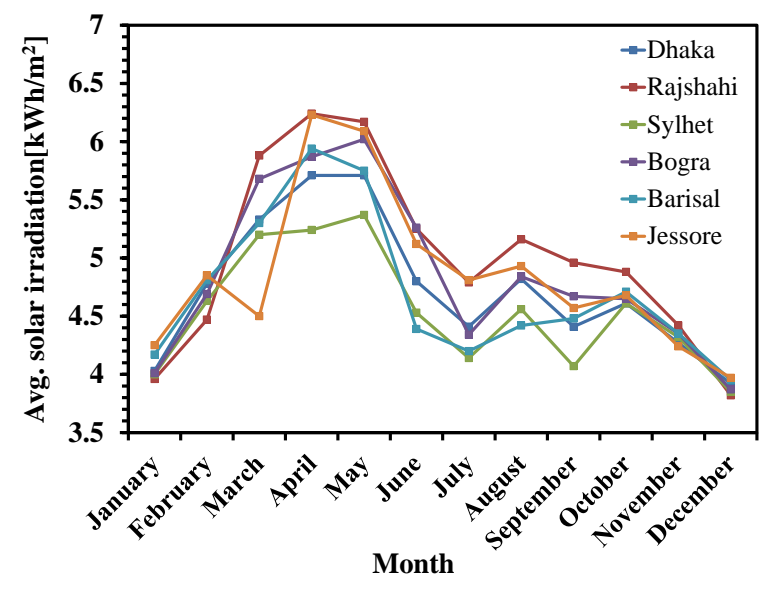

For generating electricity, a few solar energy technologies are prevalent and promising worldwide such as solar home system (SHS), solar PV and concentrating solar power (CSP). Potential of those solar energy technologies are also high in case of Bangladesh shown in Table 1.

Table 1: Solar energy potential in Bangladesh ${ }^{6)}$

\begin{tabular}{|l|c|}
\hline \multicolumn{1}{|c|}{ Technology } & $\begin{array}{c}\text { Potential power } \\
\text { (MW) }\end{array}$ \\
\hline SHS & 234 \\
\hline Grid-connected solar PV & 50,174 \\
\hline CSP & 234 \\
\hline
\end{tabular}

\subsection{Usage and progress of solar energy}

Bangladesh has started to use the solar energy for power generation comprehensively from last few years which is essential for moving towards sustainable development and to ensure energy security. At present, $54 \%$ solar energy share exists among the total RE in the country ${ }^{9}$. Currently using solar energy technologies are SHS, solar irrigation, solar power plant, solar drinking water system, solar street light, solar mini-grid and solar rooftop. Bangladesh achieved remarkable success in the SHS.

\subsubsection{Solar home system}

In SHS, PV panel is used to generate electricity. The purpose of launching SHS in Bangladesh was to make sure electricity access of off-grid rural people. This system helps to shift kerosene and diesel which were used in lamps and generators respectively. Bangladesh has achieved tremendous success in SHS. Up to now, the total no. of installed SHS is 5.2 million with $218.48 \mathrm{MW}$ capacities 16). Infrastructure Development Company Limited (IDCOL) is a major contributing company which installed 4.5 million SHS out of total 5.2 million SHS. The other 0.7 million SHS was installed mainly by Bangladesh Rural Electrification Board (BREB), German Organization for Technical Cooperation (GIZ), Infrastructure Development Company Limited (TR/ KABIKHA project). The increasing trend of SHS installation of last seven years is shown in fig. 6 .

From fig. 6, it is observed that from the year 2011 to 2017 the number of SHS increases more than four times. Besides, the number of SHS installation in last five years is 3.3 million that brings almost 150 million people into the access of electricity.

Fig. 5: Average monthly solar irradiation ${ }^{15)}$ 


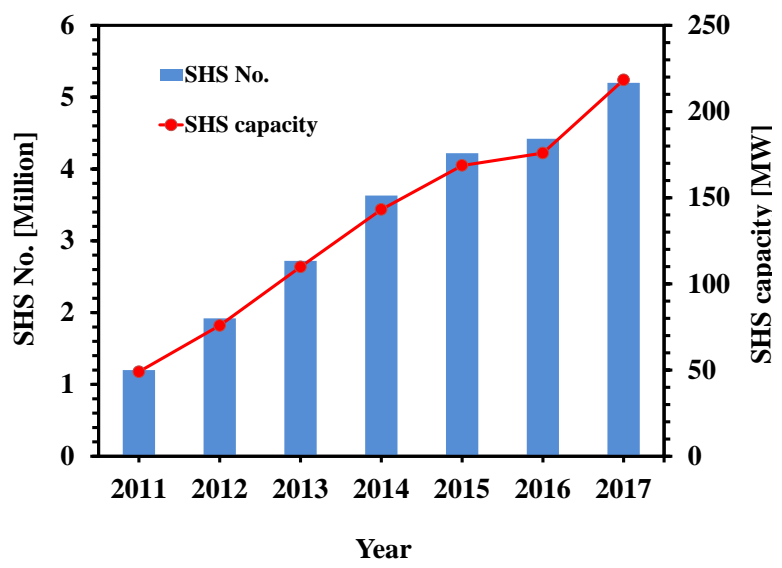

Fig. 6: Increasing trend of SHS installation ${ }^{9)}$

\subsubsection{Solar irrigation}

One of the fundamental driving forces of Bangladesh's economy is agriculture, which adds $18.64 \%$ of its GDP ${ }^{9}$. Therefore, it is imperative to enhance the agricultural production sustainably. Irrigation has a considerable significance in this country's agriculture. At present, there are approximately 1.34 million diesel-powered pumps running for irrigation purposes ${ }^{9)}$. The government has already set the objective to replace all diesel-powered pumps by solar driven pumps, consequently, it will make possible to generate $150 \mathrm{MW}$ of electricity from irrigation sector. To the year of 2017, total implemented solar irrigation pump capacity is 18.03 MW where more than $96 \%$ installation was done by IDCOL. In this case, IDCOL acts as a fund manager. Besides, very few solar irrigation units were installed by BREB and Bangladesh Agricultural Development Corporation (BADC). The increasing trend of solar irrigation is displayed in fig. 7. Still government needs to go a long way toward fulfilling the target of 150MW.

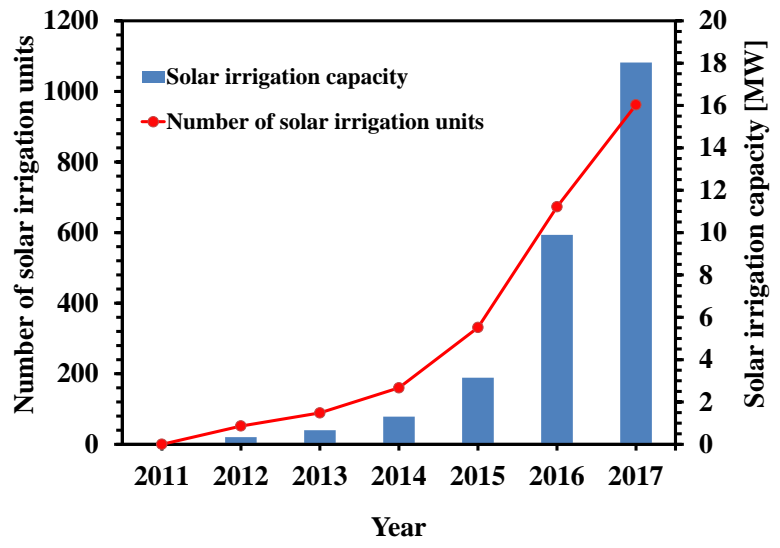

Fig. 7: Increasing trend of solar irrigation ${ }^{9)}$

\subsubsection{Solar power plant}

Very recently, from 3rd August 2017, a 3MW solar power plant has successfully started to produce electricity and supply to the national grid. This is the first ever solar power plant in Bangladesh located at Shimla bazaar, Sarishabari of Jamalpur with eight acres of land. This is a milestone for Bangladesh in solar energy which other can follow.

This solar power plant has been added 8,00,000 kWh electricity to national grid line from its starting to mid-October 2017. Within two and half months of its operation, it was able to reduce the burning of almost 2,00,000 liters of diesel comparing with same amount of electricity production from diesel power plant ${ }^{17)}$.

\subsubsection{Solar pump for drinking water}

Solar powered drinking water system can ensure safe water supply by eliminating arsenic, salinity and other impurities from water. This technology has high demand in coastal areas where there is scarce of safe drinking water. Bangladesh government has started to install solar pump for drinking water a few years ago. At present, the number of the installed solar pump for drinking water is 152 with a total capacity of $1.55 \mathrm{MW}^{9}$.

\subsubsection{Solar street light}

Bangladesh has recently started to use solar energy for street light. In 2017, the total numbers of installed solar street light are 34194 with a 2.32 MW capacity. This project is implemented by IDCOL(TR/KABIKHA) ${ }^{9}$.

\subsubsection{Solar mini-grid}

As national grid cannot be expanded easily in remote off-grid areas, therefore, it is a big challenge to provide electricity in those places. To make the electricity available to remote places, the government has already taken several initiatives and identified 30 off-grid locations where there is no plan to expand grid line in next $15-20$ years. Solar mini grid project is one the great initiatives to make electricity access for deprived rural people. The government has given financial support to IDCOL mainly to establish the solar mini-grid projects.

Up to now, 11 mini-grids has been successfully installed and are in operation. The total capacity of installed solar mini-grid is 2.19 MW. Besides, 15 more mini-grid with 3.17 cumulative capacity is in under process. However, a $650 \mathrm{kWp}$ solar mini-grid at Shalla, Sunamganj has been established by BPDB that is the biggest mini grid project in south asia ${ }^{9}$.

\subsubsection{Solar rooftop}

The government has taken initiatives to use the roof-top of commercial and residential buildings to install the solar PV system. This solar roof-top project has been started from 2014. From the beginning to now, the total installed capacity of the solar roof-top project is 
almost $30 \mathrm{MW}^{9)}$.

\subsection{Future potential solar energy technology for Bangladesh}

As Bangladesh is blessed to have a huge amount of solar energy due to her geographical location, therefore, solar powered technologies have high potential in this country. Already few technologies have successfully implemented. However, one future potential technology is a solar-powered desiccant system, which can be used for drying purpose of different kinds of agricultural products/ foods storage. Cooling technologies powered by $\mathrm{RE}$ has great potential at farm level cold storage in this country ${ }^{18)}$. To meet the increasing air-conditioning load demand of the country, solar adsorption cooling can be an alternative which is almost zero electricity technology ${ }^{19)}$. Another use of solar energy can be solar thermal energy production in large scale for industrial and domestic hot water supply ${ }^{20,21)}$.

\section{Key factors of solar energy progress}

\subsection{Main contributed renewable energy policies}

\subsubsection{Private sector power generation policy of Bangladesh, $1996^{22)}$}

With the Private Sector Power Generation Policy of Bangladesh, approved in 1996, the government has decided to allow the private sector in power generation. The government has permitted private investors for establishing power plants and retailed electricity to the government. To encourage the private investors, the government has offered several attractive incentive packages. Bangladesh government has provided payment guarantee to project company through implementation agreement. The project company will get assistance in getting clearances from various government agencies. Besides, the project company will get an exemption from corporate income tax for a period of 15 years. Under this policy, the government has also offered to import plant and equipment and spare parts (10\% of original plant cost) without payment of customs duties, VAT and any other surcharges. Avoidance of double taxation on the basis of bilateral agreements has been ensured under the policy. To recover the foreign direct investment, the company will be allowed to convert Bangladeshi currency Taka to the corresponding foreign currency.

Therefore, this policy has a huge contribution to enhance the private investor participation in the power sector.

\subsubsection{Guidelines for remote area power supply system, 2008}

After implementing the Private Sector Power Generation Policy of Bangladesh, many potential entrepreneurs exposed interest in that idea; however, satisfactory progress has not been ended so far. Therefore,
Remote Area Power Supply System (RAPSS) was commenced to accelerate the power supply in remote areas. The primary purpose of this guideline was to move faster the coverage of electricity in remote and isolate areas with the private sector investment. Under this policy, the government will offer the project land to the private investor for the development and operation of power generation utility including the electricity distribution and retail supply system for a period up to 20 years.

Under the policy of RAPSS ${ }^{23)}$, the government will allow small power generation and distribution projects on the basis of a short-period concession. Besides, the project will be permitted within the structure of the existing policies. The government will provide the project area to the investors that are far from the national grid line especially in rural and coastal areas. The government also decided to approve on-grid tariff nearly equivalent to that of REB.

\subsubsection{Renewable energy policy of Bangladesh, 2008} 24)

This policy was adopted to accelerate and promote the usage of RE in Bangladesh. The RE policy aimed to establish a dedicated organization for development and promotion of sustainable and renewable energy to meet $5 \%$ of total power demand from RE sources by 2015 and $10 \%$ by 2020 . Moreover, it has an important role to facilitate investment and to provide fiscal incentives for $\mathrm{RE}$ based projects provided the provision of $10 \%$ higher tariff in RE based projects than the highest purchase price of electricity by the utility from private generators.

Under this policy, the government established sustainable and renewable energy development authority (SREDA). According to the target set by this policy to meet power demand, the target was fulfilled partially up to 2015 and hopefully the target for 2020 will be fulfilled in due time. The provision of fiscal incentives and $10 \%$ higher tariff encouraged many investors and entrepreneurs in RE based projects.

\subsubsection{Sustainable and renewable energy development authority}

SREDA was formed in December 2012 as a nodal agency to promote and facilitate sustainable and renewable energy. It also acts as a safeguard to energy mix and energy security.

SREDA has taken several initiatives ${ }^{25}$ like formulation and revision of existing policies, rules, regulations to support RE based projects. For renewable energy and energy efficiency development, SREDA will set a year-wise target and prepare a program to achieve the targets and monitor the progress. SREDA also works to standardize the renewable energy as well as energy-efficient products/appliances. On a regular basis, they arrange a meeting with the stakeholders to coordinate 
and monitor the activities of sustainable energy. This organization is also in charge for designing and implementation of different social and cultural programs such as involving school children in energy-related affairs, essay competition, seminars, symposiums, TV talk shows, fairs, video clips etc.

\subsubsection{Special Act -2010 for quick procurement in power and energy sector and its subsequent amendment 2015}

This policy was taken to ensure the rapid process of procurement of power and energy through unsolicited proposals from the private entrepreneurs without engaging in the lengthy tendering process. Under this policy, any entrepreneur can submit a project proposal to power division for RE-based power project development with detail report regarding land, evacuation, technology, feasibility and tariff. After evaluation, the power division may go for tariff negotiation and after successful negotiation; Letter of Intent (LOI) will be issued to successful proposed projects.

\subsection{International influences}

One of the main driving factors of the solar energy progress is the influence of the foreign funding agencies. SHS installation has been driven by technical and financial support from various development partners like Asian Development Bank (ADB), World Bank, Islamic Development Bank, German Development Cooperation (GIZ), Global Environment Facility, International Development Association and German Government owned Development Bank (Kreditanstalt für Wiederaufbau), Department for International Development of the United Kingdom, Global Environment Facility, Global Partnership on Output-Based Aid (a multi-donor trust fund), Japan International Cooperation Agency, SNV, United States Agency for International Development and so on ${ }^{26)}$.

From 2008 to the end of 2015, ADB provided USD 33 million loans for IDCOL's SHS program ${ }^{26)}$. World Bank supported project named Second Rural Electrification and Renewable Energy Development (RERED II) project, helped the farmers of Bangladesh to install solar irrigation pumps to replace the conventional diesel and electric pumps. World Bank committed to providing USD 155 million for the RERED II project ${ }^{27}$ ).

World Bank supported electrification project enabled Bangladesh to gain carbon credits (Certified Emission Reductions, CER) for lowering greenhouse gas emissions under the UNFCCC's Clean Development Mechanism (CDM). The program is targeted to achieve 1.1 million carbon credits by 2016. The companies involved in the project shared the revenue earned by selling the carbon credit to the World Bank's Community Development Carbon Fund ${ }^{28)}$.

\subsection{Solar panel price reduction}

Solar panel price reduction has a significant influence on solar power progress in Bangladesh. Fig. 8 shows the solar panel price history for the year 1977 to 2014. It is evident from the figure that almost $97 \%$ price reduction is occurred within the year 1977 to 2010 . Therefore, the installation cost is reduced largely after 2010 and it becomes affordable for rural people which make them interested to use solar energy ${ }^{26)}$.

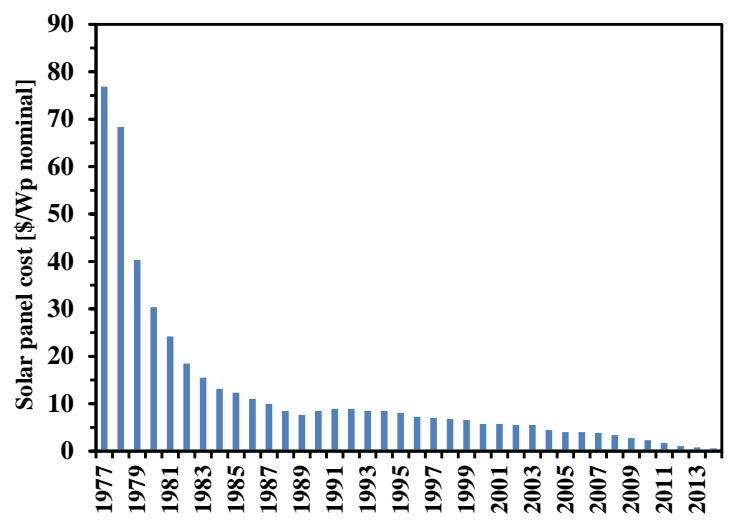

Fig. 8: Solar panel price history ${ }^{26)}$

\subsection{Private sector participation}

Private sector participation has played a significant role in the progression of solar energy in small scale like Grameen Shakti, Srizony Bangladesh, BRAC, Navana Renewable Energy Limited etc. Several big solar power based projects are going to be implemented by private companies. At present, three big projects are going to be implemented by the sponsorship of private organization. A 200 MW capacity Independent Power Plant (IPP) in Teknaf, Coxs Bazar by SunEdison, $50 \mathrm{MW}$ in Mymensing by Hetat-IFDC-Ditrolic and $32 \mathrm{MW}$ in Sunamganj by Edisun-Powerpoint-Haor Bangla are going to be implemented.

\subsection{Public awareness}

Public awareness is an important factor for the flourishment of solar energy. Bangladesh Government has taken so many initiatives to make the nation conscious about renewable energy and energy efficiency. The government has started schooling program, where different types of energy efficiency and renewable energy related videos are shown to the students. In addition, students are asked to make their family and neighbor conscious about using renewable energy as well as using energy efficiently. Another initiative to create awareness among children is to perform an essay competition on renewable energy-related topic, which is selected by national committee every year ${ }^{29)}$. Besides, government holds different debate program and art competition on the renewable energy-related theme at the 
school level. An exhibition like National Renewable Energy Expo is also for creating awareness among the general people. People have become interested in using RE based equipment and systems like solar pump, SHS etc. In urban areas, people are installing rooftop solar PV systems to meet some portion of building energy demand.

\section{Conclusions}

For the flourishment of solar energy in Bangladesh, the major contributing factors are found government policy and initiatives, international influence as well as as solar panel price reduction. Besides, private participation in the energy sector and public awareness also played an imperative role.

To fulfill the future solar energy target, the government can take more initiatives like fiscal incentives to encourage mass people and private investors. Several countries of the world have high advancement in solar energy; therefore, it will be worthy to make an analysis of those countries policies to be followed by Bangladesh government.

\section{Acknowledgments}

The authors would like to thank Green Asia Program in Kyushu University and Japanese Government for providing research funding.

\section{References}

1) K Hossain, A. \& Badr, O. Prospects of renewable energy utilisation for electricity generation in Bangladesh. Renew. Sustain. Energy Rev. 11, 1617-1649 (2007).

2) Population of Bangladesh. Available at: http://www.worldometers.info/world-population/ bangladesh-population/. (Accessed: 31st March 2018)

3) Bangladesh - Literacy rate. Available at: https://countryeconomy.com/demography/literac y-rate/bangladesh. (Accessed: 30th March 2018)

4) Maps of World. (2017). Available at: https://www.mapsofworld.com/bangladesh/bangl adesh-political-map.html. (Accessed: 12th March 2018)

5) Bangladesh - Rural population. Available at: https://tradingeconomics.com/bangladesh/rural-p opulation-percent-of-total-population-wb-data.ht ml. (Accessed: 26th March 2018)

6) Halder, P. K., Paul, N., Joardder, M. U. H. \& Sarker, M. Energy scarcity and potential of renewable energy in Bangladesh. Renew. Sustain. Energy Rev. 51, 1636-1649 (2015).

7) Ahamad, M. \& Tanin, F. Next power generation-mix for Bangladesh: Outlook and policy priorities. Energy Policy 60, 272-283 (2013).

8) Annual report. Available at: http://www.bpdb.gov.bd/bpdb/index.php?option= com_content\&view=article\&id=75\&Itemid=81.

(Accessed: 15th March 2018)

9) Sustainable energy. Available at: http://www.sreda.gov.bd/index.php/site/re_prese nt_status. (Accessed: 15th March 2018)

10) Power System Master Plan 2010. Available at: http://www.bpdb.gov.bd/download/PSMP/PSMP 2010.pdf. (Accessed: 20th May 2017)

11) REthinking Energy. (2017). Available at: http://www.irena.org/DocumentDownloads/Publi cations/IRENA_REthinking_Energy_2017.pdf.

12) Barai, M. K. \& Saha, B. B. Energy Security and Sustainability in Japan. Evergr. Jt. J. Nov. Carbon Resour. Sci. Green Asia Strateg. 2, 49-56 (2015).

13) Gima, H. \& Yoshitake, T. A Comparative Study of Energy Security in Okinawa Prefecture and the State of Hawaii. Evergr. Jt. J. Nov. Carbon Resour. Sci. Green Asia Strateg. 3, 36-44 (2016).

14) Jacobson, M. Z. Review of solutions to global warming, air pollution, and energy security. Energy Environ. Sci. 2, 148-73 (2008).

15) Rofiqul Islam, M., Rabiul Islam, M. \& Rafiqul Alam Beg, M. Renewable energy resources and technologies practice in Bangladesh. Renew. Sustain. Energy Rev. 12, 299-343 (2008).

16) Initiative \& programs. Available at: http://www.sreda.gov.bd/index.php/site/page/b80 1-2127-49bf-12e5-29d6-d4e9-b122-56ac-56cb-5 e93. (Accessed: 25th May 2017)

17) Engreen. Available at: http://engreen.com.bd/index.php/pages/ledLight Gallery. (Accessed: 20th March 2018)

18) Mahmood, M. H., Sultan, M., Miyazaki, T. \& Koyama, S. Desiccant air-conditioning system for storage of fruits and vegetables: Pakistan preview. Evergr. Jt. J. Nov. Carbon Resour. Sci. Green Asia Strateg. 3, 12-17 (2016).

19) Rouf, R. A., Hakim Khan, M. A., Ariful Kabir, K. M. \& Saha, B. B. Energy management and heat storage for solar adsorption cooling. Evergr. Jt. J. Nov. Carbon Resour. Sci. Green Asia Strateg. 3, 1-10 (2016).

20) Hasan, M., Mahadi, M., Miyazaki, T., Koyama, S. \& Thu, K. Exergy Analysis of Serpentine Thermosyphon Solar Water Heater. Appl. Sci. 8, 391 (2018).

21) Mahadi, M. S.-U.-R., Hasan, M. F., Ahammed, A., Kibria, M. T. \& Huque, S. Construction, fabrication and performance analysis of an indigenously built serpentine type thermosyphon solar water heater. 2014 3rd Int. Conf. Dev. Renew. Energy Technol. 1-6 (2014). 


\section{doi:10.1109/ICDRET.2014.6861712}

22) Private Sector Power Generation Policy of Bangladesh. (1996).

23) Ibrahim A.S.Al Mohtad. Remote Area Power Supply Systems (RAPSS). in Himalayan Small Hydropower Summit (2006).

24) Renewable Energy Policy of Bangladesh. (2008).

25) Strategic Planning. Available at: http://www.sreda.gov.bd/index.php/site/page/f3f1 -eb2f-ae16-d014-fc7c-af01-8d1b-f8cb-8e33-291 5. (Accessed: 12th May 2017)

26) Marro, P. \& Bertsch, N. Making Renewable Energy a Success in Bangladesh: Getting the Business Model Right by Asian Development Bank. (2015).

27) Solar Program Brings Electricity to Off-the-Grid Rural Areas in Bangladesh. Available at: http://www.worldbank.org/en/news/feature/2016/ 10/10/solar-program-brings-electricity-off-grid-r ural-areas. (Accessed: 20th March 2018)

28) World Bank. Available at: http://blogs.worldbank.org/climatechange/lightin g-rural-bangladesh-rooftop-solar-carbon-credits. (Accessed: 12th March 2018)

29) Awareness program. Available at: http://www.sreda.gov.bd/index.php/site/page/a49 9-5b05-0d3f-c9ee-420a-9115-411f-89a7-38cc-43 dd. (Accessed: 19th May 2017) 